\title{
RESEARCH OF FACTORS INFLUENCING THE PROCESS OF FORMATION OF WELDED MICROCONNECTIONS IN ELECTRONIC MODULES
}

\author{
Igor NEVLIUDOV ${ }^{1}$, Murad OMAROV ${ }^{2}$, Iryna BOTSMAN ${ }^{1}$, \\ Nataliia DEMSKA ${ }^{1}$, Viktoriia NEVLIUDOVA ${ }^{1}$, Mykola STARODUBCEV ${ }^{1}$ \\ ${ }^{1}$ Department of Computer-Integrated Technologies, Automation and Mechatronics, \\ Kharkiv National University of Radio Electronics, Kharkiv, Ukraine \\ ${ }^{2}$ Facultyof Automatics and Computerized Technologies, Kharkiv National University of Radio Electronics, Kharkiv, Ukraine
}

\begin{abstract}
The features of the formation of microconnections in electronic modules on an aluminum-polyimide basis by the method of ultrasonic welding, which allows to obtain reliable mounting joints of different thickness aluminum without preliminary removal of oxide films where the use of contact welding and soldering are practically difficult or impossible, are investigated. The influence of technological modes (power of an ultrasonic generator, oscillation amplitude of a welding tip (tool), welding force and welding time) on the reliability of mounting microconnections is considered.
\end{abstract}

Keywords: Electronic modules, Microconnection, Polyimide, Ultrasonic welding, Technological modes

\section{INTRODUCTION}

In the practice of modern Assembly technology of electronic modules based on aluminium-polyimide flexible printed circuits (FPC) in the process of installation is widely used ultrasonic (US) micro welding. Compared to the electronics used in other methods of mounting the ultrasonic bonding has a number of advantages [1-2]:

- has wide opportunities for automation of technological process of Assembly;

- enables connection raznoformatnyh conductors without removing the oxide film;

- allows to reach high productivity of the process of installation;

- ensures consistent achievement of required standards of accuracy, which positively affects the quality and reliability of finished products in General;

- provides simplicity and manufacturability of the welding process.

To ensure the reliability of welded joints and, consequently, the structures of electronic modules based on a FPC, there is a need to study the physico-chemical processes occurring during the formation and fracture of welded joints obtained by ultrasonic welding to implement the necessary structural and technological characteristics of micro [2-4].

\section{ANALYSIS OF THE INFLUENCE OF CONSTRUCTIVE-TECHNOLOGICAL FACTORS ON THE KINETICS OF FORMATION OF WELDED INSTALLATION COMPOUNDS}

Ultrasonic welding of metal microconductors is based on the use of the energy of mechanical vibrations of the welding tip. The oscillations are made with an ultrasonic frequency of over $16 \mathrm{kHz}$ and an amplitude of oscillation at the level of 0.5-50 microns. Energy is introduced into the welding zone by means of a welding force that is within the limits $(0,1 \div 1,0) \cdot \sigma_{T}$ for the material being welded $\left(\sigma_{T}\right.$ yield strength of the material).

*Corresponding Author: nataliia.demska@nure.ua

Received:14.10.2019 Published: 16.12.2019 
The process of formation of a welded mounting joint is characterized by a complex interaction of numerous and heterogeneous factors [1]. On the one hand, this is a complex of phenomena associated with intensive processes of external friction, temperature increase in the materials being welded, cracking of solid and burning out of fatty films, increased ductility, curing of micro- and macroirregularities, convergence of contacting surfaces at a distance close to interatomic, etc. On the other hand, it is a complex of phenomena related to the condition, ability of the energy path to supply this energy to the welding zone.

The main quantities that determine the transfer of energy to the welding zone are the vibrational stresses and velocities that occur at the welding tip and, ultimately, in the welding zone.

The main technological parameters of the welding mode of metal conductors are the power of the ultrasonic generator, the amplitude of the welding tip (tool) $\xi$ the welding force $F$ and the welding time [2].

A significant effect on the strength of the mounting joint during ultrasonic microwelding is exerted by the compression force, which causes the occurrence of tangential stresses at the welding site. The optimal compression force increases with increasing thickness of the welded elements and the size of the welded joint and significantly depends on the input power. The greater the compression force, the greater should be the amplitude of the vibration of the tool and the required electrical power.

If the installation capacity exceeds the required thickness or diameter for welding this material, then an increase in the compression force leads to excessive deformation of the weld point and a decrease in the joint strength.

In case of insufficient compression force, the necessary adhesion between the tool and the upper welded part is not achieved. The tool creeps over the part; no weld is formed.

When considering the relationship between the tool oscillation amplitudes and the compression force from the point of view of the constancy of energy release in the welding zone, it is recommended to reduce the compression force with an increase in the tool oscillation amplitude for a given mechanical power of the ultrasonic oscillatory system. It is noted that the compression force should increase in proportion to the amplitude of the tool's vibrations with a corresponding increase in the power of the oscillatory system.

A number of researchers found that the duration of welding increases with the thickness of the material, hardness and decrease in electrical power. It is noted that there is an extreme nature of the dependence of the strength of welding micro-compounds on the duration of the welding cycle. The decrease in strength with a long time of microwelding is explained in most cases by an increase in the total deformation and the appearance of cracks in the weld zone.

The energy of ultrasonic vibrations depends on the amplitude and frequency as follows

$$
E=\xi \cdot f \cdot \tau,
$$

where $\xi-$ microwelding amplitude; $f-$ microwelding vibration frequency; $\tau$ - microwelding time.

These expressions show that while maintaining the power level necessary for welding, a decrease in the amplitude of oscillations can be compensated by a corresponding increase in frequency.

In addition, it was found that high quality joints in ultrasonic microwelding is achieved with a certain ratio of all mode parameters. 
The duration of ultrasound activation required for microwelding is determined by the amplitude of oscillations and the compression force.

The amplitude of the oscillations is related to the vibrational velocity $V$ as

$$
V=2 \cdot \pi / \xi \text {. }
$$

\section{MATERIALS AND METHODS OF RESEARCH}

The objectives of the research conducted by the authors of the study were to study and analyze:

- reliability of mounting connections on a polyimide carrier [4];

- the correct choice of design solutions and technological modes of the assembly and installation of experimental FPC samples with structural elements;

- the possibility of further development, if necessary, of the design and technology of the FPC according to the test results.

Under the conditions of the formation of a welded microconnection of aluminum FPC leads, the researchers found that the thickness of the aluminum metallization layer on the FPC should be at least 10 microns. A decrease in thickness leads to a decrease in the weld strength of the FPC micro-leads [5]. Experimental studies were carried out for a two-layer aluminum-polyimide test sample FPC, the main structural parameters of which are given in table. one.

Table 1. Design parameters of the FPC test sample

\begin{tabular}{|l|c|}
\hline \multicolumn{1}{|c|}{ Parameter } & Value \\
\hline \multicolumn{2}{|c|}{ Overall dimensions of FPC: } \\
\hline - length, mm & 75 \\
\hline - width, mm & 150 \\
\hline - thickness, $\mu \mathrm{m}$ & 50 \\
\hline \multicolumn{2}{|c|}{ Conductors width, $\boldsymbol{\mu m : ~}$} \\
\hline - bottom layer between conductors, $\boldsymbol{\mu m :}$ \\
\hline - top layer & 350 \\
\hline \multicolumn{2}{|c|}{200} \\
\hline - bottom layer & 250 \\
\hline - top layer & \\
\hline
\end{tabular}

The formation of mounting joints was carried out on an automatic installation of ultrasonic welding EM4092, which allows for precision high-density installation in automatic mode. As a working tool during installation, a needle for ultrasonic welding of the type IU1-130-21 was used. The working end of the welding tool is made in the form of cross-shaped grooves. This ensures a reliable mechanical contact of the output with the welding tool.

To analyze the reliability of installation, we studied the influence on this characteristic of the main parameters (factors) of the process: loading (compression) forces $P[\mathrm{~N}]$, power $N[\mathrm{~W}]$ and welding time $t_{w}[\mathrm{~s}]$.

The reliability of the welded mounting joint was assessed by the tensile strength of the joint [6].The following factors were also taken into account: the fracture force during the tensile tests $\mathrm{F}[\mathrm{H}]$, the relative deformation of the test sample FPC $\varepsilon$ [\%], the coefficient of variation in strength $\gamma$ [\%]. The dependences of the relative strain $\varepsilon$ on the mode of the installation process make it possible to more fully interpret the strength of the joint, and also give some ideas about the mechanism of the process of joint 
formation during U3 welding. The coefficient of variation of strength $\gamma$ allows us to judge the reliability of the mounting connection, depending on the installation modes [7].

The coefficient of variation of strength was calculated as follows:

$$
\gamma= \pm \frac{\sigma}{F_{a r}} \cdot 100 \%
$$

where $F_{a r}-$ the arithmetic mean value of the efforts of destruction; $\sigma$-average deviation:

$$
\sigma= \pm \sqrt{\sum_{i=l}^{n} \frac{\left(F_{i}-F_{c e p}\right)^{2}}{n-1}},
$$

where $F_{i}$ - fracture force for the i-th welded joint; $n$-number of test compounds.

\section{EXPERIMENTAL RESEARCH RESULTS}

\subsection{Development of An Experimental-Statistical Model of the Installation Process of Electronic Modules by Ultrasonic Welding using The Results of A Full Factorial Experiment}

During experimental studies, the optimal technological parameters of the ultrasonic welding operation were established, in particular, the limiting welding conditions were determined to ensure the necessary strength of the obtained mounting joints.

Stably high reliability of microconnections was ensured in the experimentally established range of optimal technological modes of ultrasonic welding: pulse duration - from 300 to $400 \mathrm{~ms}$; power of ultrasonic vibrations - from 1.75 to $2.25 \mathrm{~W}$; tool loading force - from $0.4 \mathrm{~N}$ to $0.7 \mathrm{~N}$.

Thus, the quality and reliability of the obtained mounting connections mainly depends on the following technological factors: output power of the ultrasonic generator $x_{1}[\mathrm{~W}]$, welding time $x_{2}[\mathrm{~ms}]$, the force applied to the working tool, $x_{3}[\mathrm{~g}]$. The task was set using a complete factorial experiment to find a mathematical description of the installation process in the vicinity of the base point with coordinates $x_{01}=2 \mathrm{~W}, x_{02}=350 \mathrm{~ms}, x_{03}=40 \mathrm{~g}[6,8]$.

Based on the results of a complete factorial experiment, an experimental-statistical model of the installation process of electronic modules by ultrasonic welding is developed:

$$
\hat{y}=17,87+0,3563 x_{1}+0,2288 x_{2}+1,3713 x_{3}+0,2113 x_{1} x_{2}+0,2188 x_{1} x_{3},
$$

where $\dot{y}$ - mechanical strength of the mounting joint; $x_{1}$ - ultrasonic generator output power; $x_{2}-$ welding time; $x_{3}$ - welding tool load.

The experimental results coincide with the data obtained as a result of theoretical studies.

\subsection{Investigation of the Dependence of The Fracture Force of A Welded Joint on The Load Force of A Working Tool}

First of all, the area of permissible installation modes was determined. For integral estimation in experiments, the method of constructing threshold curves was used. To do this, with a gradual increase in the load force $P$ and power $N$ of the ultrasonic generator, welding was performed followed by a separation test and comparison with the levels of allowable joint strength. 
In Fig. 1 shows the typical dependencies that form such areas of installation modes: I - the area of modes that ensure the strength of welded joints less $15 \times 10-2 \mathrm{~N}$; II - the area of valid modes; III - the range of modes that provide welded joints with excessive deformation (more than 50\%).

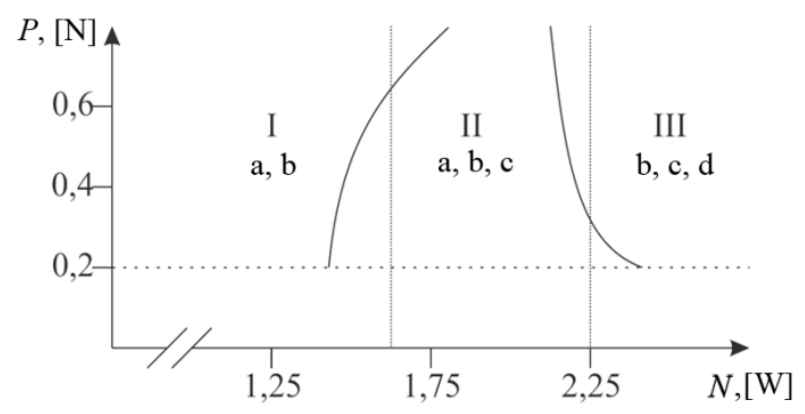

$\mathrm{a}, \mathrm{b}, \mathrm{c}, \mathrm{d}$ - type of destruction of the welded joint along the conductor, behind the heat-affected zone, along the welded joint and separation with a break in the conductor, respectively

Figure 1. Areas of permissible welding modes by constructing threshold curves depending on the power $N$ and the load force $P$.

Within the range of permissible welding modes, the dependences of the fracture force of the welded microconnect $\mathrm{F}$ and the coefficient of variation $\gamma$ on the main welding modes (load force, power and welding time) were taken. The dependence $F=f(P)$ has its maximum, which determines the optimal conditions for energy transfer without loss from the welding tool to the welding site (Fig. 2).

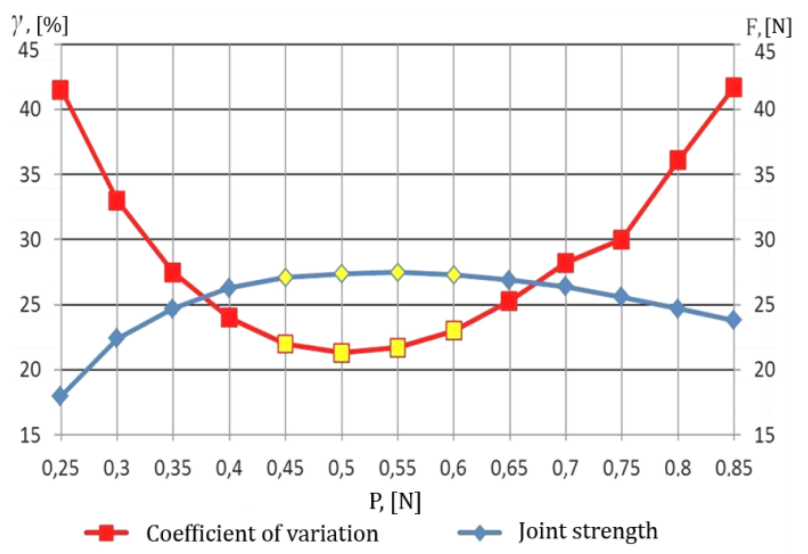

Figure 2. Dependences of the strength of the mounting joint $F$ and coefficient of variation of strength on the load force of the welded tool $P$.

As a result of experimental studies, it was found that an excessive increase in the compression force prevents the flow of slip processes in the contact zone, which leads to a decrease in the strength of the welded joint. At the same time, stability stability can be estimated by the coefficient of variation in strength. The increase in the coefficient is associated with a decrease in stability and, conversely, an increase in stability leads to a decrease in the coefficient.

\subsection{Assessment of The Reliability of Microconnections}

To assess the failure rate of structural elements of a two-layer flexible switching board $\lambda_{0}$ according to the results of tests of small samples with single failures, the hypothesis on the form of the distribution function of time to failure according to the $\chi^{2}$ criterion (hi-square) was clarified [7]: 


$$
\lambda_{0}=\frac{\chi^{2}}{N \cdot k \cdot t},\left(\text { hours }^{-1}\right),
$$

where $\chi^{2}$ - failure criterion (with a zero number of failures and a confidence level of $60 \%$, the value $\chi^{2}=1,833$ ); $N=2625$ - the number of welds of the investigated FPC (sample size); $k=1$ - the number of FPC samples that were investigated; $t=100$ ч - MTBF (the time during which the tests were conducted FPC).

Thus, according to expression (1), the failure rate of the microconnects of the studied FPC was

$$
\lambda_{0}=\frac{1,833}{2625 \cdot 1 \cdot 100}=6,8 \cdot 10^{-6}\left(\text { hours }^{-1}\right) .
$$

At the same time, MTBF amounted to

$$
t_{H}=\frac{1}{\lambda_{0}}=\frac{1}{6,8 \cdot 10^{-6}} \approx 142857 \text { (hours) }=16 \text { (years). }
$$

\section{CONCLUSION}

The results of the studies indicate a high level of reliability and stability of the technology of assembly and installation of electronic modules.

Thus, based on the conducted studies, the topological requirements for the elements of the microcontact node can be formulated as follows:

- the location of the flat conductors of the upper layer of the horizontal layer should correspond to the location of the conductors of the lower layer;

- the optimal width of the aluminum output of the upper layer should be 15-20 microns less than the linear size of the output of the lower layer;

- the distance between the contact zone of the microwelding and the polyimide frame should be at least 30 microns.

Thus, the experimentally established optimal mode of the microwelding process is characterized by achieving maximum joint strength with minimal electrical contact resistance. At the same time, the surface condition of the materials used has a noticeable effect on the installation process parameters..

\section{REFERENCES}

[1] Заводян А.В., Грушевский А.М. Анализ сборочно-монтажных процессов производства электронных средств. Москва: МИЭТ, 2005, 200 с. [Analysis of assembly and installation processes of the production of electronic sredstv. Moscow, MIET, 2005, 200 p.].

[2] Хмелев В.Н., Шалунов А.В., Хмелев С.С., Цыганок С.Н. Ультразвук. Аппараты и технологии: монография. Бийск: Изд-во Алт. гос. техн. ун-та, 2015.

[3] Tricomi A. The CMS Inner Tracker Silicon Microstrip Modules: Production and test // Nuclear Instruments and Methods in Physics Research. Section A: Accelerators Spectrometers Detectors and Associated Equipment, 2007, Vol. 570 (2), N 1, PP. 248-252.

[4] Борщов В.Н., Невлюдов И.Ш., Проценко М.А., Тымчук И.Т., Хатнюк И.С. Исследование и выбор оптимальных технологических режимов сварки для автоматизации монтажа гибких алюминий-полиимидных микрокабелей. Технология приборостроения. 2011, №1, С. 3-8. 
[5] Балабанов В.Т. Технология создания плоских микромодулей для приборов бесконтактной идентификации: автореф. дис. к.Т.н. [Московский гос. ин-т электронной техники]. М., 2008, $26 \mathrm{c}$.

[6] Невлюдов И.Ш., Андрусевич А.А., Стародубцев Н.Г., Невлюдова В.В., Малая И.А. Влияние технологических режимов операции УЗ-сварки на надежность монтажных соединений, Праці Міжнародної науково-практичної конференції «Математичне моделювання процесів в економіці та управлінні проектами і програмами (ММП-2017)», Коблево, 12-13 вересня 2017 р., Харків: ХНУРЕ, 2017, С. 142-145.

[7] Невлюдов І.Ш, Боцман І.В, Невлюдова В.В, Разумов-Фризюк Є.А. Технологічне забезпечення якості гнучких комутаційних структур: монографія. Кривий Ріг: КК НАУ, 2018.

[8] Ponomareva AV, Nevlyudova VV. The ultrasonic welding operations technological regimes impact on the process connections reliability. Radiotekhnika: All-Ukr. Sci. Interdep. Mag., 2012, №170, PP. 143-148 (article in Russian with an abstract in English). 